\title{
Ekmeğin Besinsel Özelliklerinin İyileştirilmesi
}

\author{
Hacer MERAL *iD Mehmet Murat KARAOĞLU \\ Atatürk Üniversitesi, Ziraat Fakültesi, Gıda Mühendisliği Bölümü, Erzurum, Türkiye \\ ("Sorumlu yazar e-mail: hacer.meral@ atauni.edu.tr) \\ DOI: 10.17097/ataunizfd.496393
}

Geliş Tarihi (Received Date): 04.12.2018

Kabul Tarihi (Accepted Date): 19.03.2019

\begin{abstract}
ÖZ: Buğdayın tarımının yapılmaya başlandığı zamandan günümüze kadar insanlar beslenmelerinde ekmeğe yer vermişlerdir. Son zamanlarda, rafine undan yapılan ekmek tüketiminin artması buğdayda bulunan önemli besin maddelerinin vücuda alımını kısıtlamaktadır. Yetersiz ve dengesiz beslenme günümüzün önemli beslenme sorunlarını oluşturmaktadır. Özellikle dar gelirli kesim başta olmak üzere, toplumun dengeli beslenmesi için ekmeğin zenginleştirilmesi araştırıcıların dikkatini çekmektedir. Baklagillerden balığa, yağlı tohumlardan çesitli meyve-sebzelere kadar birçok ürün ekmeğin zenginleștirilmesinde kullanılmıș ve olumlu sonuçlar alınmıștır. Gıda sanayinde kullanılan çeșitli besin değeri yüksek gıda a(r)tıkları bile ekmeğin zenginleștirilmesinde kullanılabilmektedir. Ekmeğin bu gibi bileşenlerle fonksiyonel hale getirilmesi tüketicinin de dikkatini çekmekte ve bu ürünlere olan ilgi gün geçtikçe artmaktadır. Karbonhidrat içeriğinin yüksek olmasından dolayı enerji ve glisemik indeksi değeri yüksek olan normal ekmeğin protein, mineral madde, esansiyel yağ asidi, fenolik madde ve diyet lifi gibi beslenmede önemli olan maddeler bakımından zenginleștirilmesi mümkün olmaktadır. Protein kaynaklarına ulaşmanın zorlaştığı günümüzde, proteince zenginleștirilmiş ekmeğin tüketimi bu eksikliği giderebilir. Son zamanlarda obezite, kardiyovasküler ve diyabet gibi hastalıklar oldukça yaygınlaşmıştır. Bu hastalıkların yaygınlaşmasında diyet lifi tüketiminin düşüklüğü ve hareketsiz yaşam tarzının benimsenmesi büyük öneme sahiptir. Günlük diyette önemli bir yer tutması nedeni ile ekmeğin diyet lifi bakımından zenginleştirilmesinin bu gibi hastalıkların görülme sıklığını azaltmada önemli işlev üstleneceği açıktır.
\end{abstract}

Anahtar Kelimeler: Ekmek, Beslenme, Ekmeğin zenginleştirilmesi, Fonksiyonel gıda

\section{Improvement of Nutritional Properties of Bread}

\begin{abstract}
People have given place to bread in their nutrition from the time of wheat agriculture to nowadays. Recently increasing white bread consumption has limited taking essential nutrients from whole wheat to body. It seems that inadequate and unbalanced diet constitutes today's important nutritional problems. Researchers are attracted to the bread enrichment in order to balance the nutrition of the every individuals in society, especially people with low income. From legumes, fish, oil seeds to a variety of fruits and vegetables like many products were used to bread enrichment and positive results were obtained. Even some of food industry residue, which contain high nutritional value, can be used to bread enrichment. The functionalization of bread with such components also interest to consumers and interest in these products is increasing day by day. Due to the high carbohydrate content, wheat bread with high energy and glycaemic index can be enriched with substances that are important in nutrition such as protein, mineral, essential fatty acid, phenolic substance and dietary fibre. It is difficult to access the protein resources nowadays but consumption of the bread, which is enriched with protein, can overcome this deficiency. Low dietary fibre consumption and sedentary lifestyle are thought to be of great importance in the prevalence of these diseases. It is certain that dietary fibre enrichment of the bread, which has taken a significant place in our diet, can reduce the incidence of such diseases.
\end{abstract}

Keywords: Bread, Nutrition, Bread fortification, Functional food

\section{GíRIŞ̧}

Fonksiyonel gidalara olan talep gün geçtikçe artmakta ve son zamanlarda fonksiyonel firıncilik ürünleri daha fazla gündeme gelmektedir (Rahaie et al., 2014). Ekmek dünyanın her yerinde üretilen ve en çok tüketilen gidalardan biridir. Ekmeğin protein ya da diğer gıda bileşenlerince zenginleştirilmesi yetersiz beslenmenin önüne geçmede en etkin yollardan biri olarak görülmektedir (Menon et al., 2015; Callejo et al., 2016). Birleşmiş Milletler Gida ve Tarım Örgütü'ne (FAO) göre zenginleştirme; popülasyonda veya belirli bir popülasyonda bir ya da daha fazla besin maddesinin kanıtlanmış eksikliğinin önlenmesi veya düzeltilmesi amaciyla, normal olarak gidada bulunup bulunmamasından bağımsız olarak, temel besin maddelerinin gidaya eklenmesidir (Anonim, 1995). Gelişmekte olan ülkelerde, tahıl ürünlerine dayalı bir beslenme yaygin olmakla birlikte, toplumun önemli bir kısmı dengeli beslenme için yeterince bütçe ayıramamaktadır. Diğer gıda maddelerine göre daha ekonomik, ulaşılması daha kolay ve beslenme alışkanlıkları bakımından daha çok tüketilen ekmeğin çeşitli besin bileşenleri bakımından zenginleştirilmesi toplumun önemli bir kısmının dengeli ve sağliklı beslenmesinin sağlanmasında önemli bir yere sahiptir (Hobbs et al., 2014; Cavalcante et al., 2016).

Son yıllarda insanların yaşam tarzlarının değişmesi sonucunda fiziksel aktivite azalması ve beslenme alışkanlıklarındaki değişiklikler, tip 2 diyabet, kalp hastalıkları ve bazı kronik hastalıkların artmasına yol açmıştır. Beslenme alışkanlıklarındaki en önemli değişiklikler yüksek lifli gıdalar, tam tahıllar, meyve ve sebzeler yerine hizlı sindirilebilen karbonhidrat bakımından zengin "fast food" türü tüketimin artmasıdır. Diyette besinsel lif oranının azalması ve glisemik indeksi yüksek gıdaların tüketiminin artması kronik hastalıkların 
yaygınlaşmasının önemli bir sebebi olarak gösterilmektedir. Beslenmede, yüksek lif ve düşük glisemik indeksli gidalara daha fazla yer verilmesi, glisemik kontrolünün sağlanmasının yanı sıra vücut ağırlığının yönetimini de kolaylaştırdığı bir gerçektir. Obezite ve tip 2 diyabet, kalp hastalığı riskini artırıcı yönde etkili olurken, yüksek lif içerikli gıdalarla beslenme serum lipidinden kaynaklanan risk faktörlerinin yanı sıra diğer biyomarkırları da modifiye ederek kalp hastalığı riskini azaltmaktadır (Hu et al., 2009; Kendall et al., 2010; Hager et al., 2011).

Son yıllarda, proteince zengin gidaların, ekmeğin zenginleştirilmesinde kullanılmasına yönelik yapılan araştırmaların sayısı oldukça artmıştır. Özellikle alternatif bitkisel protein kaynakları, ekmeğin dokusal ve duyusal kalitesine uyumluluğundan dolayı, bu alanda gittikçe önem kazanmaktadır (Föste et al., 2014). Baklagiller, sebzeler, süt ve balık gibi gıdalar ekmeğin zenginleştirilmesinde kullanılarak olumlu sonuçlar alınabilmektedir. Günümüzde ekmek hala insanların beslenmesinde en temel gıda maddesidir. Öğütme aşamasında buğdayın, besin değeri yüksek rüşeym ve fonksiyonel özelliklere sahip kepek kısımları ayrıldığı için özellikle rafine undan üretilen ekmek ve benzeri firın ürünlerinde besin değerinin önemli derecede düştüğü belirtilmiştir (Indrani et al., 2015; Pasqualone et al., 2017).

Günümüzde, tüketici bilincinin artmasına paralel olarak sağlıklı ve fonksiyonel gıdalara olan ilgi de artmaktadır. Düşük fiyatından dolayı, gelir düzeyi düşük insanların kolay ulaşabildiğgi en temel gıda maddesi olan ekmek genelde iyi bir karbonhidrat, dolayısıyla günlük diyette iyi bir enerji kaynağıdır. Bununla birlikte, özellikle rafine undan yapılan ekmekler protein, mineral, esansiyel yağ asidi ve diyet lifi açısından yeterli bir kaynak değildir. Bu sebeple, özellikle ekmeğin protein, besinsel lif, vitamin ve minerallerce zenginleştirilmesi üzerine yapılan çalışmalar büyük önem arz etmektedir. Fırın ürünlerinin zenginleştirilmesinde başta bitkisel kaynaklı olmak üzere, proteince zengin gidalardan elde edilen karışımlar kullanılmaktadır (Bastos et al., 2014; Diana et al., 2014; Indrani et al., 2015).

\section{Ekmeğin baklagil ve diğer proteinli gıdalar ile zenginleştirilmesi}

Fasulye, mercimek, nohut ve soya gibi baklagiller iyi bir protein, nişasta ve diyet lifi kaynağıdır. Baklagillerin, özellikle protein içeriklerinin yüksek olması, bu ürünleri ekmeğin zenginleştirilmesinde kullanılmaları için çekici hale getirmektedir. Bu bitkiler kuru ağırlıklarının \%18.530'u kadar protein, \%35-52'si kadar nişasta ve \%14.626.3'ü kadar da diyet lifi içerirler. Bu gıdalar yüksek oranlarda lisin, lösin, aspartik asit, glutamik asit ve arjinin içermekte ve tahıllar ile birlikte tüketildiğinde dengeli bir amino asit alımını sağlamaktadırlar (Mohammed et al., 2012; Mondor et al., 2014; Bigne et al., 2016; Summo et al., 2016; Turfani et al., 2017).

Baklagiller tahılların aksine, kükürt içeren amino asitler açısından yetersiz olmalarına rağmen yüksek oranda lisin içerirler. Soya, nohut, fasulye, yulaf kepeği gibi gıda maddelerinin öğütülerek rafine undan yapılan ekmeğe katılmaları bu ekmeğin besin kalitesini olumlu yönde etkilemektedir. Bu sebepten rafine undan yapılan ekmeğin, baklagil unları ile zenginleştirilmesi, günlük diyette esansiyel amino asitlerin yeterli seviyede alınmasını sağlayabilmektedir. Yalnızca amino asitlerle kalmayıp baklagiller insan sağlığı üzerinde antitrombotik ve tansiyonu düşürücü gibi olumlu etkilere sahip olan çeşitli biyoaktif peptitleri de içermektedirler. Ayrıca, fasulyede bulunan Glu-Phe, Ile-Arg ve Lys-Phe gibi peptitlerin antitrombotik etki gösterdikleri ve baklagil tüketiminin kolesterolü düşürdüğü de rapor edilmiştir (Mohammed et al., 2012; Bigne et al., 2016; Summo et al., 2016).

Yapılan çalışmalarda baklagillerin kardiyovasküler hastalıklar, tip 2 diyabet, bazı kanser türleri, fazla kilo ve obezite riskini azalttığ belirlenmiştir. Proteinlere ilave olarak baklagiller yüksek miktarlarda karbonhidrat, diyet lifi, vitamin, mineral, oligosakkarit ve fenolik maddeler içermektedirler. Baklagil unları ile zenginleştirilmiş hamur, içerdiği fenolik maddeler sayesinde, serbest radikalleri yakalayarak antioksidan özellik göstermektedir. $\mathrm{Bu}$ gibi olumlu katkılarına rağmen baklagil unlarının rafine undan yapılan ekmeğe ilave edilmesi hamur yapısını zayıflattığı için ekmek hacmi ve ekmek içi elastikiyetini düşürmekte ve ekmek içinin sertliğini artırmaktadır. Yapılan çalışmalarda optimum tüketim kalitesine sahip ekmek üretimi için baklagil unlarının genel olarak \%10 (w/w) seviyesinde rafine undan yapilan ekmek üretiminde kullanılabileceği belirtilmiştir (Rizzello et al., 2014; Indrani et al., 2015 ).

Fırıncılık ürünlerinde amino asit dengesinin geliştirilebilmesi için çimlendirilmiş baklagillerden elde edilen unların da bu ürünlerin üretiminde kullanılabileceği bildirilmektedir. Ekmeğin protein içeriğinin artırılması amacıyla yapılan çalışmalarda, farklı seviyelerde $(\% 10, \% 20, \% 30)$ nohut unu ilavesinin, ekmeğin besin ve tüketim kalitesi üzerine etkileri araştırılmış ve \%20 ilave seviyesine kadar hamurun teknolojik özelliklerinin kontrol grubu örneklere yakın değerler verdiği belirtilmiştir (Mohammed et al., 2012; 2014).

Mercimek ve beyaz fasulyeden ekstrakte edilen proteinler teknolojik özellikler açısından çalışılmış ve bu protein ekstraktlarının ekmek üretiminde kullanılmasının ekmek içi yumuşaklık değerleri üzerine olumlu yönde etkili olduğu bildirilmiştir. 
Beyaz fasulye ve mercimek proteinleri yüksek su bağlama kapasitesine sahip oldukları için, firıncılık ürünlerinde yalnızca besin değerini attırmakla kalmayıp, aynı zamanda ürün tazeliğini artırarak raf ömrünün uzamasına olumlu yönde etki etmektedir. $\mathrm{Bu}$ üstün özelliklerine rağmen, mercimek ve beyaz fasulye proteinlerini içeren bir diyet metiyonin amino asidinin alımının yetersizliğine neden olabilmektedir. Metiyonin amino asidi, metebolizmada protein sentezini başlatmak gibi önemli fonksiyonlara sahiptir. Bu eksiklik, metiyonince zengin diğer tahıllar ve dengeli bir diyetle kapatılabilmektedir (Bildstein et al., 2008).

Börülce gibi baklagiller protein (esansiyel amino asit), karbonhidrat, diyet lifi, vitamin (tiamin, niasin, riboflavin, pridoksin ve folik asit), mineral $(\mathrm{P}, \mathrm{Fe}, \mathrm{K}$, $\mathrm{Mg}, \mathrm{Zn}$ ve $\mathrm{Mn}$ ), düşük miktarda lipit ve doymamış yağ asitleri gibi gıda bileşenleri bakımından dengeli beslenme için oldukça önemli bir yere sahiptir. Börülce unu ilavesi ile firıncılık ürünlerinde demir, bakır, fosfor, magnezyum, manganez, çinko gibi mineraller artırılabilmektedir. Ayrıca, ekmeklik una börülce unu ilavesiyle elde edilen ekmekler standart formüle kıyasla daha düşük kalori değerine sahip olmaktadır. Geleneksel nişasta kaynaklarıyla (manyok, patates, mısır, pirinç) kıyaslandığında, börülceden elde edilen nişastanın, firıncılık ürünlerinin teknolojik kalitesini de yükselttiği belirtilmektedir. Börülcede bulunan nişasta sayesinde hamur daha düşük bir özgül ağırlığa sahip olduğu için ürünün hacmini artırmakta, rengini açmakta ve depolama süresince nemin azalmasını engellemektedir. Ayrıca, börülce gluten içermediğinden çölyak hastaları için üretilen glutensiz firıncıllk ürünlerinin zenginleştirilmesinde de rahatlıkla kullanılabilmektedir (Cavalcante et al., 2016).

Kabuğu soyulmuş bakla ununun buğday ununa ilave edildiği bir çalışmada (Abdel-Kader, 2001), üretilen ekmeklerin protein, yağ, kalsiyum, fosfor ve demir içeriklerinin arttığı belirlenmiş̧ir. Bakla unu, buğday ununa göre daha yüksek oranda lisin ve histidin amino asidi içermektedir. Bakla ununun ilave edildiği örneklerde tüm esansiyel amino asit miktarlarının arttığı ifade edilmekle birlikte yalnızca metiyonin miktarının düştüğü belirlenmiştir. $\mathrm{Bu}$ durum baklanın metiyonin oranının buğdaya nazaran daha düşük olmasından kaynaklanmaktadır.

Kinoa tohumunun ekmeğin zenginleştirilmesinde kullanıldığ olumlu sonuçlar elde edilmiştir. Kinoa, $100 \mathrm{~g}$ kuru madde de $\% 14$ ile $\% 20$ arasında protein içermektedir. Kinoa da baskın olarak bulunan amino asitler diğer tahıllarda daha az miktarlarda bulunan metiyonin, lisin ve treonindir. Gluten proteinlerini içermemesi, kinoanın çölyak hastalarının beslenmesinde kullanılma potansiyelini artırmaktadır. Yüksek protein içeriğinin yanı sıra kinoa; kalsiyum, demir, çinko ve magnezyum minerallerince de oldukça zengindir. Ekmek gibi firıncılık ürünlerinin kinoa ile zenginleştirilmesinin çölyak hastalarının yanı sıra, yetersiz beslenme ile karşı karşıya olan bireyler için de faydalı olacağı belirtilmektedir (Föste et al., 2014; Swieca et al., 2014; Rizzello et al., 2016; Demir ve K1lınç, 2016; Giritlioğlu ve Dizlek, 2018).

Maş fasulyesi (Vigna radiata), baklagiller familyasindan olup protein, diyet lifi, mineral ve vitaminler açısından oldukça zengindir. Maş fasulyesinin protein oranı yaklaşık \%24 olup tahılların yaklaşık olarak üç katı kadardır. Indrani et al. (2015), tarafından yapılan bir çalışmada, maş fasulyesi ekmeğin zenginleştirilmesinde kullanılmış ve ekmeklik unun maş fasulyesi ile katkılanmasıyla ekmeklerin protein ve diyet lifi miktarının önemli derecede artırılabileceği bildirilmiştir.

Thinopyrum intermedium, Triticeae takımına ait genellikle hayvan beslenmesinde kullanılan çok yıllık bir bitkidir. Avrupa, Batı Asya ve Kuzey Afrika'da endemik bir tür olarak yetiştirilmekle birlikte günümüzde dünyanın çeşitli yerlerinde de yetiştirilmeye başlanmıştır. T. intermedium protein ve esansiyel amino asitlerce oldukça zengin olup, sistein ve metiyonin içeriği buğdaya göre 1.4 kat daha fazladır. Bu bitkinin tohumu buğdaya nazaran daha küçük olduğundan, kabuk ve diyet lifi oranı da buğdaydan fazladır. Ekmeğin bu bitkinin unu ile zenginleştirilmesinin, protein içeriğinin yanı sıra diyet lifi içeriğini de artıracağı bildirilmektedir (Marti et al., 2016).

Buğday ununa yağlı tohum unlarının katılması da ekmeğin besin değerinin artırılmasına yardımcı olabilmektedir. Susam ununun buğday ununa katılması ile ekmeğin protein, mineral, esansiyel amino asit ve özellikle buğdayda az olan lisin açısından zenginleşeceği belirtilmektedir (El-Adawy, 1995).

Ekmeğin tek bir kaynak yerine farklı kaynaklardan elde edilen karışımlarla zenginleştirilmesi de söz konusudur. Yapılan bir çalışmada, tam yağlı soya, çimlenmiş maş fasulyesi ve mango çekirdeği unlarından elde edilen karışımlar ekmeğin zenginleştirilmesinde kullanılmış ve bu karışımlar ilave edilerek üretilen ekmeklerin protein içerikleri önemli derecede artarken fiziksel özellikleri kontrol ekmeğine yakın bulunmuştur. Organoleptik analizlerde ise meyve çekirdeği unlarının miktarının artmasının renk ve tat puanlarını düşürdüğü bildirilmiştir. Sonuç olarak bu kaynakların, ekmeğin özellikle protein bakımından zenginleştirilmesinde kullanılabileceği ve mango çekirdeği gibi yağlı tohumların doğal yağ ikamesi olarak formülasyonlara ilave edilebileceği belirtilmiştir (Menon et al., 2015).

Ekmeğin soya unu ile zenginleştirilmesi besinsel değerini artırmasının yanı sıra hamurun su tutma ve 
şişme kapasitesini artırarak işlenmesini de kolaylaştırmaktadır. Soya fasulyesinin çiğ olarak kullanılması ekmeklerde istenmeyen bir fasulye tadı oluşmasına neden olmaktadır. Bu durumu engellemek için soyanın çimlendirilmesi ya da 1 sıl işlem uygulaması gerekmektedir. Protein oranının yüksek olmasının yanı sıra çeşitli mikrobesin elementleri ve fitokimyasalları da içeren soya, ekmeğin zenginleştirilmesinde kolaylıkla kullanılabilmektedir (Shin et al., 2013).

Balık işleme sanayinde büyük miktarlarda balık kalıntı ve atıkları oluşmaktadır. Balığın kendisi birçok besin maddesini ihtiva ettiği için balık kalıntıları da bu besinlerden payını almaktadır. Bu durum göz önünde bulundurularak yapılan bir çalışmada kırmızı kuyruklu Brycon (Brycon cephalus) balığının kalıntılarından elde edilen un, ekmeğin zenginleştirilmesinde kullanılmıştır. Belirtilen balık unu ilave edilerek üretilen ekmeklerde protein, esansiyel yağ asitleri, mineral maddeler (özellikle fosfor ve kalsiyum), A, D ve B kompleks vitamin miktarları artmış, karbonhidrat miktarı ise azalmıştır. Balık unu katılmış ekmeklerin duyusal özelliklerinin ise kontrol ekmeğinden daha iyi veya kontrol ekmeğine yakın olduğu belirtilmiştir. Araştırma sonuçları, düşük maliyetli balık kalıntılarının ekmeğin zenginleştirilmesinde kullanılabileceğini göstermiştir (Bastos et al., 2014).

Süt ve ürünleri de ekmeğin besin değerinin artırılmasında kullanılabilmektedir. $\mathrm{Bu}$ ürünler ekmeğin kalsiyum, protein ve bazı esansiyel amino asitlerinin (lisin, metiyonin ve triptofan gibi) miktarlarını artırabilmektedir. Ekmeği zenginleştirmenin yanı sıra süt ürünleri, hamurun işlenmesini kolaylaştırmakta ve renk, tat, kabuk tekstürü gibi kalite özelliklerini de geliştirmektedir. Peynir altı suyu tozu tahıl ürünlerinin zenginleştirilmesinde kullanılan başlıca bileşendir (Kenny et al., 2000).

\section{Ekmeğin diyet lifi oranı yüksek gıdalar ile zenginleştirilmesi}

İnce bağırsakta sindirilemeyen, buna karşılık kalın bağırsakta fermente olan, bitki hücre duvarında bulunan lignin türevleri, selüloz, hemi-selüloz, pektin gibi yap1 polimerleri, inülin ve oligofruktoz gibi oligosakkaritler diyet lifi olarak tanımlanmaktadır (Burdurlu ve Karadeniz, 2003). Diyet liflerinin günlük olarak 25-40 g tüketimi kabızlığın önlenmesi ve kolonik divertikül oluşumunun engellenmesi için önerilmektedir. Diyet lifi tüketimiyle birlikte dışkı miktarında meydana gelen artış, diyet liflerinin bağırsak içi faaliyetlerinin bir sonucudur (Scheppach et al., 2004; Le Bleis et al., 2015; Fendri et al., 2016; Noort et al., 2017). İnce bağırsakta sindirilmeyen diyet lifi, kaynağına bağlı olarak, kalın bağırsakta diyet lifindeki polisakkarit zincirler bakteriler tarafindan fermente edilebilmektedir. Baskın fermantasyon ürünlerinden özellikle asetat, propianat ve n-bütirat gibi kısa zincirli yağ asitleri kolon tarafından emilerek kolon hastalıkları ile ilgili birçok yararlı etki göstermektedirler (Scheppach et al., 2004).

Codex Alimentarius diyet lifini, insanların bağırsaklarındaki enzimler tarafından hidrolize edilemeyen ve 10 ya da daha fazla monomer yap1 içeren karbonhidrat polimerleri olarak tanımlamaktadır. Diyet lifleri dışkı kütlesini artırarak geçiş süresini kısaltmakta, kandaki toplam ve LDL kolesterol miktarını düşürmekte, yemek sonrası kan şekeri ve insülin seviyelerini azaltmakta, midedeki aşırı asitliği tamponlayarak mideyi korumaktadır. Düşük diyet lifi alımı diyabet, obezite, kronik kalp hastalıkları ve bağırsak kanseri ile ilişkilendirilmektedir. Rafine unun polisakkarit formundaki diyet lifi içeriği \%2-4 arasında değiştiğinden una diyet lifi ilave edilmesi ile ekmeğin sağlı üzerine olumlu etkilerinin artacağı ifade edilmektedir. Ekmeğin zenginleştirilmesinde yalnızca suda çözünemeyen diyet liflerinin kullanılması fonksiyonelliklerinin ve fermente olma kapasitelerinin kısıtlı olmasından dolayı istenmeyen bir durumdur. Suda çözünemeyen diyet liflerinin aksine çözünebilenler, bağırsak florasında fermente olarak istenilen metabolik etkileri gösterebilmektedirler. Suda çözünebilen diyet liflerinin (pektin, galaktomannan gibi) su tutma kapasiteleri çözünemeyen bir diyet lifi olan selülozdan daha iyidir. Suda çözünen ve çözünmeyen diyet liflerinin birlikte ekmek formülasyonuna ilave edilmesi lifin fonksiyonel özelliklerinden tam olarak yararlanılmasında daha etkili olmaktadır (Anonim, 1985; Gül ve Dizlek, 2008a; 2008b; Kotancilar et al., 2010; Kendall et al., 2010; Sivam et al., 2010; Almeida et al., 2013; Le Bleis et al., 2015; Singh et al., 2015; Summo et al., 2016).

Tam buğday ekmeğinin diyet lif, protein, vitamin ve bazı mikro besin elementler ile antioksidanlar bakımından daha zengin olduğu için sağlıklı beslenmede daha çok tercih edilmesi gerektiği bildirilmektedir. Tam buğday ekmeğinin kuru maddede diyet lifi oranı \%7-8 arasında değişirken rafine undan üretilen ekmekte bu oran \%2-3'e kadar düşmektedir. Rafine undan yapılan ekmek tüketici tarafindan daha çok tercih edildiği ve diyet lifince zayıf olduğu için, bu ekmeğin diyet lifi açısından zenginleştirilmesi çalışmalarına önem verilmesi gerektiği gündeme gelmiştir (Rubel et al., 2015).

Tam tahıl unları, diyet lif bakımından zengin kaynaklar olmakla birlikte ekmeğin lif içeriğini artırmak için hindiba, gamlar, meyve ve sebzeler de kullanılabilmektedir. Tam buğday unu insanlar için oldukça ucuz bir diyet lifi ve mikro besin elementi kaynağıdır. Üstelik bazı gıdaların glisemik indeks ve 
kalorilerini düşürmek için de kullanılabilmektedir. Yüksek miktarlarda lif içeren ekmeklerin kardiyovasküler hastalıkları engellemek, sindirim sistemini düzenlemek, kan kolesterol seviyesini düşürmek, mineral emilimini artırmak, bağışıklık sistemini geliştirmek, diyabet ve kolon kanserini önlemek gibi istenilen fizyolojik ve metabolik etkileri bulunmaktadır. Aynı zamanda, tahıllarda bulunan diyet liflerin yeterli tüketilmesi durumunda insülin duyarlılı̆̆ artmakta ve buna bağlı olarak diyabet riski azalmaktadır (Rahaie et al., 2014; Rubel et al., 2015; Kurek et al., 2017).

Hurma (Phoenix dactylifera) tohumlar1, hurmanın işlendiği işletmeler tarafından atık olarak ayrılmaktadır. Bu tohumlarda yüksek miktarlarda diyet lifi, tanin, enzime dirençli nişasta, anabolik ajanlar ve selenyum bulunması son zamanlarda fonksiyonel bir gıda artığı olarak dikkatleri üzerine çekmektedir. Ekmeğin zenginleştirilmesinde hurma tohumu ununun kullanılması ekmeklerin besin değerini artırmakta ve bayatlama süresini geciktirmektedir (Najafi et al., 2016).

Dengeli ve biyolojik aktivitesi yüksek aminoasit kompozisyonu sahip olan karabuğday (karabaş) aynı zamanda $\mathrm{Zn}, \mathrm{Cu}, \mathrm{Mn}$ gibi mikro elementler ve $\mathrm{K}, \mathrm{Na}$, $\mathrm{Ca}, \mathrm{Mg}$ gibi makro elementler açısından da oldukça zengindir. Karabuğday ununun karbonhidrat içeriği buğday ununa göre daha az olmasına rağmen, diyet lifi buğday unundan daha fazladır. Karabuğday rutin, kuersetin, kaempferol-3-rutinosid ve az miktarda flavonol trigliserid gibi yüksek antioksidan etkilere sahip flavonol glikozitlerini de içermektedir. Yapılan çalışmalar, karabuğdayın kronal kalp hastalıkları riskini azaltan, kan şekeri seviyesini düşüren ve bazı kanser tiplerini önleyen rutin flovonolünü birçok meyve-sebze ve tahıldan daha fazla içerdiğini göstermektedir. Buğday ununa karabuğday unu ilavesi bu undan üretilen ekmeğin besin değeri artırılmakla birlikte sağlığa daha faydalı hale getirmektedir (Rahaie et al., 2014).

Çeltiğin pirince dönüştürülmesi prosesinde, pirinç tanelerinin soyulması ile elde edilen pirinç kepeği; protein, mineral, yağ asidi ve diyet lifi açısından oldukça zengin bir yan üründür. Yapılan çalışmalarda, pirinç kepeğinin suda çözünmeyen kısmının yüksek miktarda diyet lifi (\%62.73) ve protein (\%8.35), suda çözünen kısmının ise yüksek miktarda diyet lifi (\%82.94) düşük miktarda protein (\%2.69) içerdiği tespit edilmiştir. Pirinç kepeği yüksek oranda diyet lifi içerdiği için dışkı miktarını artırmak, kan kolesterolünü düşürmek ve kolon kanserini önlemek gibi önemli biyolojik etkiler göstermektedir. $\mathrm{Bu}$ olumlu etkilerinden dolayı pirinç kepeğinin ekmeğin zenginleştirilmesinde kullanılabileceği belirtilmektedir (Hu et al., 2009; Rahaie et al., 2014).
Tam çavdar unu ve bu undan üretilen firın ürünleri diyet lifi, vitamin, mineral ve farklı biyolojik aktif bileşenler için iyi bir kaynaktır. Bu nedenle, çavdar ekmeği ve diğer çavdar ürünleri dışkı miktarını artırmakta, intestinal geçiş süresini kısaltmakta, ikincil safra asitlerinin konsantrasyonunu azaltmakta, kadın ve erkeklerde bağırsak fonksiyonları için faydalı ve plazmada bağırsak bakterileri tarafindan üretilen lignin, enterolakton konsantrasyonunu artırmaktadır. Epidomiyolojik çalışmalar tahıllarda bulunan diyet liflerinin kolon kanserine karşı koruyucu etkisi olduğunu göstermektedir. Çavdarın probiyotik bir bakteri olan Bifidobacterium longum gelişimini artırdığı ifade edilmektedir. Çavdar ekmeği doğrudan tüketilebileceği gibi, rafine una çavdar unu ilavesiyle ekmeğin zenginleştirilmesinde de kullanılabilmektedir (Martinez-Villaluenga et al., 2009; Koletta et al., 2014; Rahaie et al., 2014).

Fonksiyonel ve besinsel özellikleri yüksek bir tahıl olan arpanın yüksek konsantrasyonda $\beta$-Dglukan (özellikle suda çözünebilen $\beta$-glukan) içerdiği bilinmektedir. Arpanın $\beta$-glukanca zengin fraksiyonları belirli bir konsantrasyonda buğday ununa ilave edildiğinde ekmeğin hacmini artırmaktadır. $\quad \beta$-glukanın hamurdaki hava kabarcıklarını stabilize edip yapışmalarını önleyerek ekmek içi yapısını geliştirdiği ifade edilmektedir. Ayrıca yapılan çalışmalar buğday ununa arpa unu ilavesinin ekmeğin antioksidan özelliklerini de artırdığını göstermektedir. (Rahaie et al., 2014; Blandino et al., 2015).

Soya fasulyesinin protein $(\% 38-40)$, yağ $(\% 18$ 20) ve lisin (\%5-6) içeriğinin yüksek olması, bu baklagili protein ve kalori açısından yetersiz beslenmenin aşılmasında önemli bir potansiyel haline getirmektedir. Yapılan çalışmalarda, soya ve arpa ununun ayr1 ayr1 ya da birlikte sirasiyla $\% 10$ ve $\% 15$ oranında ekmeğe ilave edilmesinin, ekmeğin duyusal özelliklerini bozmadan bunun protein, lisin, diyet lifi, $\beta$-glukan ve mineral içeriğini önemli derecede artırdığı belirtilmiştir (Rahaie et al., 2014).

Fındık içi üretiminde firçalama ve kavurma işlemlerinden sonra elde edilen findık iç kabuğu antioksidan özelliğe sahip bazı fenolik bileşenler ve diyet lifi bakımından oldukça zengin bir yan üründür. Findıkkabuğu ununun buğday ununa ilavesi ile üretilen ekmeklerde kabuk rengi oldukça koyulaşmış, en iyi ekmek hacmi kontrol örneğinde görülürken, $\% 5$ findıkkabuğu içeren ekmeklerin hacmi kontrole en yakın bulunmuştur. Buğday ununa \%5 ile \%10 arasında findıkkabuğu unu ilavesi ile üretilen ekmeklerde tüketim kalitesi fazla bozulmadan ekmeğin diyet lifi ve antioksidan madde içeriğinin önemli derecede artırılabileceği bildirilmiştir (Anıl, 2009).

İnülin ticari olarak en çok karahindibadan elde edilmekte ve acımsı bir tat barındırmaktadır. 
Yerelmasından elde edilen inülinin acımsı tat içermemesi bu ürünün firıncılık ürünlerinin zenginleştirilmesinde kullanılmasını daha olağan kılmaktadır. Rubel et al. (2015) tarafindan yapilan çalışmada, yerelmasından ekstrakte edilen inülince zengin karbonhidrat tozu ekmeğin diyet lifi açısından zenginleştirilmesinde kullanılmış ve yerelmasından elde edilen ekstraktın prebiyotik aktivitesinin, karahindibadan elde edilenden daha yüksek olduğu tespit edilmiştir. Rafine undan yapılan ekmeğin \%5 yerelması ekstraktı ile zenginleştirilmesi ekmekte istenilmeyen özelliklerin oluşmasına sebep olurken, $\% 2.5$ oranında yapılan zenginleştirme önemli değişikliklere yol açmamış ve rafine undan yapılan ekmeğin inülince zengin yerelması ekstraktı ile zenginleştirilmesini mümkün kılmıştır.

\section{Ekmeğin diğer bileşenlerce zenginleştirilmesi}

Biyolojik olarak aktif bileşikler olan fitokimyasallar, güçlü antioksidan aktiviteleri nedeni ile antiviral, antialerjik, antimutajenik ve antikanserojenik özelliklere sahip olmakla birlikte birçok kronik hastalığın önlenmesinde de etkilidirler. Özellikle meyve sebzeler ve tam tahıllar fenolik bileşikler bakımından oldukça zengindir. Tahıl taneleri, içerdikleri fitokimyasal maddeler (fenolik bileşikler, karotenoidler ve E vitamini) nedeniyle iyi bir doğal besinsel antioksidan kaynağıdırlar. Buğdayda bulunan fenolik asitlerin önemli bir kısmı, tanenin alöron, perikarp ve embriyo hücre duvarlarında bulunmakta ve buğdayın öğütülmesi sırasında besinsel antioksidanlarca zengin kepek tabakası uzaklaştırılmaktadır (Yılmaz, 2011; Bagdi et al., 2016). Dolayısıyla rafine undan yapılan ekmeklerin antioksidan aktivitesi çok düşük olup bu ekmeklerin antioksidanca zenginleştirilmesi büyük önem arz etmektedir. Yapılan bir çalışmada (Yılmaz, 2011), meyve suyu endüstrisinde yan ürün olan nar kabuğundan elde edilen ekstrakt, ekmek formülasyonuna ilave edilerek ekmeğin antioksidan aktivitesi artırılmaya çalışılmış, tüketim kalitesi göz önünde bulundurularak $5 \mathrm{~g} / \mathrm{kg}$ nar kabuğu ekstraktı ile ekmeklerin antioksidan aktivitesi bakımından zenginleştirilebileceği bildirilmiştir.

Zerdeçal, yüksek miktarlarda fenolik madde içeren doğal bir antioksidandır. \%4 oranında zerdeçal ilavesinin, ekmeğin tat ve tekstürel özelliklerinde fazla bir olumsuz etkiye sebep olmadan antioksidanca zenginleştirilmesini mümkün kılmaktadır. Benzer olarak fenolik maddelerce zengin ebegümeci, yeşil çay, üzüm çekirdeği, nar kabuğu, limon kabuğu, guava gibi meyveler, soğan zarı dâhil bazı sebzeler ve tahıl ürünlerinin de ekmeğin zenginleştirilmesinde kullanılabileceği belirtilmektedir (Swieca et al., 2013; Rahaie et al., 2014; Alves and Perrone, 2015; Fu et al., 2015; Gawlik-Dziki et al., 2015; Fakhfakh et al., 2017).
Keten tohumu, özellikle omega 3, omega 6 yağ asitleri, çeşitli antioksidanlar, fenolik bileşenler, diyet lifi ve lignin bileşenleri bakımından oldukça zengindir (Borlu, 2009; Bartkiene et al., 2014; Seczyk et al., 2017). Bu gida bileşenlerinin, kardiyovasküler hastalıklar, kanser, menopoz ve prostat gibi birçok hastalığın önlenmesinde önemli rol oynadığ belirtilmiştir. Borlu (2009) tarafından yapılan bir çalışmada keten tohumu ve çimlenmiş keten tohumu unları lavaş ekmeği üretiminde kullanılmış ve özelikle çimlenme ile omega 3 ve omega 6 yağ asitleri oranının $\operatorname{arttığı,~\% 10~oranında~keten~tohumu~ve~çimlenmiş~}$ keten tohumu unu ilavesinin lavaş ekmeği için olumlu sonuçlar verdiği ve keten tohumunun bu ekmeklerin zenginleştirilmesinde kullanılabileceği belirtilmiştir.

Hobbs et al. (2014), yaptıkları araştırmada ekmeği pancar, kırmızı pancar, havuç, domates, kırmızıbiber ve kişniş otu ile zenginleştirerek tüketici beğenisindeki değişimi incelemişlerdir. Kontrol olarak rafine undan yapılan ekmek esas alınmış ve meyveler ile zenginleştirilmiş ekmekler ile kontrol grubu arasında tüketici beğenisi açısından önemli bir fark olmadığ bulunmuştur. Ekmek, bu gibi meyveler ile zenginleştirilerek meyvelerin yapısında bulunan yararlı bileşenlerin tüketiminin artırılabileceği belirtilmiştir.

\section{SONUÇ}

Ekmeğin çeşitli besin kaynakları kullanılarak zenginleştirilmesi ile toplumda farklı ekonomik seviyelerdeki bireylerin yetersiz ve dengesiz beslenmelerinin önüne geçilebileceği düşünülmektedir. Rafine undan yapılan beyaz ekmeğin glisemik indeksi yüksek olmakla birlikte protein, diyet lifi ve bazı yararlı gıda bileşenleri içeriği oldukça yetersizdir. $\mathrm{Bu}$ derlemede ekmeğin zenginleştirilmesinde kullanılabilecek gıda ve gıda bileşenleri üzerinde durulmuştur. Yapılan araştırmalarda, birçok gıda ve gıda bileşeninin, rafine una tavsiye edilen oranlarda ilavesi ile duyusal özelliklerin korunarak, ekmeğin zenginleştirilmesinde kullanılabileceği belirtilmektedir. Beslenmemizde önemli bir yere sahip olan ekmeğin, zenginleştirilmesi çalışmaları yetersiz ve dengesiz beslenmenin önlenmesine büyük katkı sağlayacağı ve günümüzde oldukça sık görülen diyabet, obezite, kanser ve kardiyovasküler hastalıkların oranının da düşmesine önemli derecede yardımcı olacağı düşünülmektedir.

\section{KAYNAKLAR}

Abdel-Kader, Z.M., 2001. Enrichment of Egyptian 'Balady' bread. Part 2. Nutritional values and biological evaluation of enrichment with decorticated cracked broad beans flour (Vicia faba L.). Nahrung/Food, 1: 31-34.

Almeida, E.L., Chang, Y.K., Steel, C.J., 2013. Dietary fibre sources in bread: Influence on 
technological quality. LWT - Food Sci. and Tech., 50: 545-553.

Alves, G., Perrone, D., 2015. Breads enriched with guava flour as a tool for studying the incorporation of phenolic compounds in bread melanoidins. Food Chemistry, 185: 65-74.

Anil, M., 2009. Using of hazelnut testa as a source of dietary fiber in breadmaking. J. of Food Eng., 80: 61-67.

Anonim, 1985. Codex Alimentarius Commission, Guidelines on Nutrition Labelling. CAC/GL, 21985 .

Anonim, 1995. FAO Technical Consultation on Food Fortification: Technology and Quality Control. ISBN 92-5-103884-8. Food and Agricultural Organization, Rome.

Bagdi, A., Toth, B., Lorincz, R., Szendi, S., Gere, A., Kokai, Z., Sipos, L., Tömösközi, S., 2016. Effect of aleurone-rich flour on composition, baking, textural, and sensory properties of bread. LWT Food Sci. and Tech., 65: 762-769.

Bartkiene, E., Schleining, G., Juodeikiene, G., Vidmantiene, D., Krungleviciute, V., Rekstyte, T., Basinskiene, L., Stankevicius, M., Akuneca, I., Ragazinskiene, O., Maruska, A., 2014. The influence of lactic acid fermentation on biogenic amines and volatile compounds formation in flaxseed and the effect of flaxseed sourdough on the quality of wheat bread. LWT - Food Sci. and Tech., 56: 445-450.

Bastos, S.C., Tavares, T., Pimenta, M.E.D.S.G., Leal, R., Fabrício, L.F., Pimenta, C.J., Nunes, C.A., Pinheiro, A.C.M., 2014. Fish filleting residues for enrichment of wheat bread: chemical and sensory characteristics. J. Food Sci. Tech., 51(9): 2240-2245.

Bigne, F., Puppo, F.C., Ferrero, C., 2016. Fibre enrichment of wheat flour with mesquite (Prosopis spp.): Effect on breadmaking performance and staling. LWT - Food Sci. and Tech., 65: 1008-1016.

Bildstein, M., Lohmann, M., Hennigs, C., Krause, A., Hilz, H., 2008. An enzyme-based extraction process for the purification and enrichment of vegetable proteins to be applied in bakery products. Eur. Food Res. Tech., 228: 177-186.

Blandino, M., Locatelli, M., Gazzola, A., Coïsson, J.D., Giacosa, S., Travaglia, F., Bordiga, M., Reyneri, A., Rolle, L., Arlorio, M., 2015. Hullless barley pearling fractions: Nutritional properties and their effect on the functional and technological quality in bread-making. J. of Cereal Sci., 65: 48-56.

Borlu, M. H. 2009. Lavaş Ekmeğine Farklı Seviyelerde Keten (Linum usitatissimum) Tohumu Unu Katkılanmasının Hamur ve Ekmek Özellikleri Üzerine Etkisi, Omega 3, Omega 6
Yağ Asitleri ve Lignan Açısından Değişiminin Belirlenmesi. Pamukkale Üniversitesi Fen Bilimleri Enstitüsü, Yüksek Lisans Tezi, Denizli, Türkiye, $49 \mathrm{~s}$.

Burdurlu, S., Karadeniz, F., 2003. Gidalarda Diyet Lifinin Önemi. Gıda Mühendisliği Dergisi, 7(15): 18-25.

Callejo, M.J., Benavente, E., Ezpeleta, J.I.,Laguna M. J., Carrillo J.M., Rodríguez-Quijano,M., 2016. Influence of teff variety and wheat flour strength on breadmaking properties of healthier teffbased breads. J. of Cereal Sci., 68: 38-45.

Cavalcante, R.B.M., Morgano, M.A., Silva, K.J.D., Rocha, M. De M., Araujo, M.A.M., MoreiraAraujo, R.S.R., 2016. Cheese bread enriched with biofortified cowpea flour. Ciência e Agrotecnologia, 40 (1): 97-103.

Diana, M., Rafecas, M., Quílez, J., 2014. Free amino acids, acrylamide and biogenic amines in gammaaminobutyric acid enriched sourdough and commercial breads. J. of Cereal Sci., 60: 639-644.

El-Adawy, T.A. 1995. Effect of sesame seed proteins supplementation on the nutritional, physical, chemical and sensory properties of wheat flour bread. Plant foods for human nutrition, 48: 311326.

Fakhfakh, N., Jdir, H., Jridi, M., Rateb, M., Belbahri, L., Ayadi, M.A., Nasri, M., Zouari, N., 2017. The mallow, Malva aegyptiaca L. (Malvaceae): Phytochemistry analysis and effects on wheat dough performance and bread quality. LWT Food Sci. and Tech., 75: 656-662.

Fendri, L.B., Chaari, F., Maaloul, M., Kallel, F., Abdelkafi, L., Chaabouni, S.E., Ghribi-Aydi, D., 2016. Wheat bread enrichment by pea and broad bean pods fibers: Effect on dough rheology and bread quality. LWT - Food Sci. and Tech., 73: 584-591.

Föste, M., Nordlohne, S.D., Elgeti, D., Linden, M.H., Heinz, V., Jekle, M., Becker, T., 2014. Impact of quinoa bran on gluten- free dough and bread characteristics. Eur. Food Res. Tech., 239: 767775 .

Fu, J.T., Chang, Shiau, Y.H., Shiau, S.S., 2015. Rheological, antioxidative and sensory properties of dough and Mantou (steamed bread) enriched with lemon fiber. LWT - Food Sci. and Tech., 61: 56-62.

Giritlioğlu, E. ve Dizlek, H., 2018. Sakaroz İkamesi Olarak Farklı Tip ve Düzeylerde Şeker Otu (Stevia rebaudiana bertoni) Bazlı Tatlandırıcı Kullanılmasının Bisküvi Nitelikleri Üzerine Etkileri. Gıda Dergisi, 43 (1): 21-33.

Gawlik-Dziki, U., Kaszuba, K., Piwowarczyk, K., Świeca, M., Dziki, D., Czyż, J., 2015. Onion Skin Raw Material for The Production of 
Supplement That Enhances the HealthBeneficial Properties of Wheat Bread. Food Research Int., 73: 97-06.

Gül, H. ve Dizlek, H., 2008a. Ekmek Üretiminde Kepek Kullanılmasının Beslenme ve Sağlık Açısından Önemi. Türkiye 10. Gıda Kongresi, 21-23 Mayıs 2008, Erzurum. Gida Teknolojisi Derneği Yayın No:37, Türkiye 10. Gıda Kongresi Bildiriler Kitab1, 383-386.

Gül, H. ve Dizlek, H., 2008b. Pentozanların Hamur ve Ekmek Nitelikleri Üzerine Etkileri. Gıda Dergisi, 33 (6): 291-295.

Hager, A., Ryan, L.A.M., Schwab, C., Ganzle, M.G., O’Doherty, J.V., Arendt, E.K., 2011. Influence of the soluble fibres inulin and oat b-glucan on quality of dough and bread. Eur. Food Res. Tech., 232: 405-413.

Hobbs, D.A., Ashouri A., George T.W., Lovegrove, J.A., Methven, L., 2014. The Consemer Acceptance of Novel Vegetable Enriched Bread Products As a Potential Vehicle to Increase Vegetable Consumption. Food Research Int., 58: 15-22.

Hu, G., Huang, S., Cao, S., Ma, Z., 2009. Effect of enrichment with hemicellulose from rice bran on chemical and functional properties of bread. Food Chem., 115: 839-842.

Indrani, D., Milind, Sakhare, S.D., Inamdar, A.A., Rao, G.V., 2015. Development of protein and fiber enriched breads by supplementation of roller milled fractions of green gram. J Food Sci Tech., 52(1): 415-422.

Kendall, C.W.C., Esfahani, A., Jenkins, D.J.A., 2010. The link between dietary fibre and human health. Food Hydrocolloids, 24: 42-48.

Kenny, S., Wehrle, K., Stanton, C., Arendt, E.K., 2000. Incorporation of dairy ingredients into wheat bread: effects on dough rheology and bread quality. Eur. Food Res. Tech., 210: 391396.

Kilinç, M. ve Demir, M.K., 2016. Kinoa: Besinsel Ve Antibesinsel Özellikleri. J. of Food and Health Sci., 2 (3): 104-111.

Koletta, P., Irakli, M., Papageorgiou, M., Skendi, A., 2014. Physicochemical and technological properties of highly enriched wheat breads with wholegrain non wheat flours. J. of Cereal Sci., 60: 561-568.

Kotancılar, H., Gerçekaslan, K., Karaoğlu, M.M., Boz, H., 2010. Besinsel Lif Kaynağı Olarak Enzime Dirençli Nişasta. Atatürk Üniv. Ziraat Fak. Derg., 40 (1): 103-107.

Kurek, M.A., Wyrwisz, J., Karp, S., Brzeska, M., Wierzbicka, A., 2017. Comparative analysis of dough rheology and quality of bread baked from fortified and high-in-fiber flours. J. of Cereal Sci., 74: 210-217.
Le Bleis F., Chaunier, L., Chiron, H., Della Valle, G., Saulnier, L., 2015. Rheological properties of wheat flour dough and French bread enriched with wheat bran. J. of Cereal Sci., 65: 167-174.

Marti, A., Bock, J.E., Pagani, M.A., Ismail, B., Seetharaman, K., 2016. Structural characterization of proteins in wheat flour doughs enriched with intermediate wheatgrass (Thinopyrum intermedium) flour. Food Chem., 194: 994-1002.

Martinez-Villaluenga, C., Michalska, A., Frias, J., Piskula, M.K., Vidal-Valverde, C., Zielinski, H., 2009. Effect of Flour Extraction Rate and Baking on Thiamine and Riboflavin Content and Antioxidant Capacity of Traditional Rye Bread. J. of Food Sci., 74: 49-55.

Menon, L., Majumdar, S.D., Ravi, U., 2015. Development and analysis of composite flour bread. J. Food Sci. Tech., 52(7): 4156-4165.

Mohammed, I., Ahmed, A.R., Senge, B., 2012. Dough rheology and bread quality of wheat-chickpea flour blends. Industrial Crops and Products, 36: 196-202.

Mohammed, I., Ahmed, A.R., Senge B., 2014. Effects of chickpea flour on wheat pasting properties and bread making quality. J. Food Sci Tech., 51(9): 1902-1910.

Mondor, M., Guevremont, E., Villeneuve, S., 2014. Processing, characterization and bread-making potential of malted yellow peas. Food Bioscience, 7: 11-18.

Najafi, M.B.H., Pourfarzad, A., Zahedi, H., Ahmadian-Kouchaksaraie, Z., Khodaparast, M.H.H., 2016. Development of sourdough fermented date seed for improving the quality and shelf life of flat bread: study with univariate and multivariate analyses. J. Food Sci. Tech., 53(1): 209-220.

Noort, M.W.J., Mattila, O., Katina, K., van der Kamp, W.J. 2017. Health Bread: Wholegrain and high fibre breads with optimised textural quality. J. of Cereal Sci., 78: 1-9.

Pasqualone, A., Laddomada, B., Centomani, I., Paradiso, V.M., Minervini, D., Caponio, F., Summo, C., 2017. Bread making aptitude of mixtures of re-milled semolina and selected durum wheat milling by-products. $L W T$ - Food Sci. and Tech., 78: 151-159.

Rahaie, S., Gharibzahedi, S.Y.T., Razavi, S.H., Jafari, S.M., 2014. Recent developments on new formulations based on nutrient-dense ingredients for the production of healthy-functional bread: a review. J Food Sci Tech., 51 (11): 2896-2906.

Rizzello, C.G., Calasso, M., Campanella, D., Angelis, M.D., Gobbetti, M., 2014. Use of sourdough fermentation and mixture of wheat, chickpea, lentil and bean flours for enhancing the 
nutritional, texture and sensory characteristics of white bread. Int. J. of Food Micro., 180: 78-87.

Rubel, I.A., Perez, E.E., Manrique, G.D., Genovese, D.B., 2015. Fibre enrichment of wheat bread with Jerusalem artichoke inulin: Effect on dough rheology and bread quality. Food Structure, 3: 21-29.

Scheppach, W., Luehrs, H., Melcher, R., Gostner, A., Schauber, J., Kudlich, T., Weiler, F., Menzel, T., 2004. Antiinflammatory and anticarcinogenic effects of dietary fibre. Clinical Nutrition Supplements, 1: 51-58.

Sivam, A.S., Sun-Waterhouse, D., Quek, S.Y., Perera, C.O., 2010. Properties of Bread Dough with Added Fiber Polysaccharides and Phenolic Antioxidants: A Review J. of Food Sci.,75: 163174.

Shin, D., Kim, W., Kim, Y., 2013. Physicochemical and sensory properties of soy bread made with germinated, steamed, and roasted soy flour. Food Chem., 141: 517-523.

Singh, A., Gupta, P., Shukla, G., Wadhwa, N., 2015. Quality attributes and acceptability of bread made from wheat and Amorphophallus paeoniifolius flour. J. Food Sci. Tech., 52 (11): 7472-7478.

Seczyk, L., Swieca, M., Dziki, D., Anders A., GawlikDziki, U., 2017. Antioxidant, nutritional and functional characteristics of wheat bread enriched with ground flaxseed hulls. Food Chem., 214: 32-38.
Summo, C., Centomani, I., Paradiso, V.M., Caponio, F., Pasqualone, A., 2016. The effects of the type of cereal on the chemical and textural properties and on the consumer acceptance of pre-cooked, legume-based burgers. $L W T$ - Food Sci. and Tech., 65: 290-296.

Swieca, M., Gawlik-Dziki, U., Dziki, D., Baraniak, B., Czyz, J., 2013. The influence of proteinflavonoid interactions on protein digestibility in vitro and the antioxidant quality of breads enriched with onion skin. Food Chem., 141: 451458.

Swieca, M., Seczyk, L., Gawlik-Dziki, U., Dziki, D., 2014. Bread enriched with quinoa leaves-The influence of protein-phenolics interactions on the nutritional and antioxidant quality. Food Chem., 162: 54-62.

Turfani, V., Narducci, V., Durazzo, A., Galli, V., Carcea, M., 2017. Technological, nutritional and functional properties of wheat bread enriched with lentil or carob flours. LWT - Food Sci. and Tech., 78: 361-366.

Yılmaz, Ö.M., 2011. Türkiye'de Yetiştirilen Başlıca Buğday Çeşitlerinin Antioksidan Aktivitelerinin ve Fenolik Asit Dağılımlarının Belirlenmesi ve Ekmeğin Nar Kabuğu Ekstraktı ile Zenginleştirilmesi. Ankara Üniversitesi Fen Bilimleri Enstitüsü, Doktora Tezi, Ankara, Türkiye, $80 \mathrm{~s}$. 